九州大学学術情報リポジトリ

Kyushu University Institutional Repository

\title{
Demography of the Formosan Wood Mouse, Apodemus semotus
}

Lin, Liang-Kong

Zoological Laboratory, Faculty of Agriculture, Kyushu University

Shiraishi, Satoshi

Zoological Laboratory, Faculty of Agriculture, Kyushu University

https://doi.org/10.5109/23988

出版情報: 九州大学大学院農学研究院紀要. 36 (3/4), pp.245-266, 1992-02. Kyushu University バージョン：

権利関係: 


\title{
Demography of the Formosan Wood Mouse, Apodemus semotus
}

\author{
Liang-K ong Lin and Satoshi Shiraishi* \\ Zoological Laboratory, Faculty of Agriculture, \\ Kyushu University 46-06, Fukuoka 812, Japan \\ (Received November 14, 1991)
}

\begin{abstract}
The demography of two Apodemus semotus populations in a Cryptomeria plantation and a small isolated renewed stand of Chamaecyparis was studied from 1985 to 1989 in the Alisan area, Taiwan. The annual fluctuation in density was characterized by a highest peak in August (66.7/ha in the Cryptomeria habitat and 51.4/ha in the Chamaecyparis habitat), a slight peak in winter and declines in both autumn and spring. The high densities probably resulted largely from habitats having monospecific occupancy. Monthly survival rates and recruitment rates showed almost no significant correlation with the density values. There were some seasonal tendencies with a higher proportion of females in summer. Diet analysis in August revealed that fungi constituted the main part of the diet. Males with fully descended testes had two considerable peaks in April and August, and females were reproductively most active in late spring and autumn when the many were lactating. The highest peak at the onset of breeding in August was caused by the high percentage of new individuals including many male transients entering into the population. The spring decline in A. semotus was qualitatively similar to that in A. sylvaticus, and spacing behavior of adults might account for the modification in demographic parameters associated with the beginning of two peaks in the annual breeding cycle.
\end{abstract}

\section{INTRODUCTION}

There have been many reports on the population ecology of the genus Apodemus in Europe (Flowerdew, 1985), Japan (Nishikata, 1979; Kondo, 198'2) and China (Zhang, 1989). Although the Formosan wood mouse (A. semotus) appears to be the most common small mammal in grasslands and forests throughout Taiwan's mountain areas, its population biology has not been studied. Regular annual fluctuations of Apodemus populations have been reviewed in the forested regions of Europe (Montgomery, 1989a). One of the fundamental problems in population biology is how the number of animals is regulated. In order to understand population regulation of $\mathbf{A}$. semotus, the demographic parameters are the most worthy measurements. Hence, the purpose of this study was to elucidate the demographic parameters including population density and structure, breeding seasons and food habits as part of the ecology of A. semotus, and to discuss the mechanisms of annual fluctuations by comparison with population densities of other species in the genus A podemus.

\footnotetext{
* Reprint request to the second author.
} 


\section{STUDY AREA}

The study area was located in Alisan Alpine Forest Park $\left(23^{\circ} 31^{\prime} \mathrm{N}, 2,200 \mathrm{~m}\right.$ elevation), lying $75 \mathrm{~km}$ east Chia-Yi County, Central Taiwan. Two grids were set in two contrasting habitats; Grid A was in a 35-year-old Cryptomeria japonica plantation with a closed canopy and patchy undergrowth. Old fallen logs and tree stumps of Chamaecyparis formosensis were sparse (Fig. la). Dominant species of the ground flora were Hydrocoytle nepalensis (percentage of cover: 10\%), Ellisiohyllum pinnatum (8\%) and Polygonum chinense (4\%).

Grid B was situated $1.5 \mathrm{~km}$ east of Grid A, being in a 60-year-old naturally renewed stand of Chamaecyparis with an open crown and dense ground flora dominated by Polygonum thunbergii (23\%), Pseudosasa japonica (19\%), Selaginella doederleinii (10\%) and Ploystichum hancockii (9\%) (Fig. lb). It was surrounded by Cryptomeria plantations where the undergrowth was cleared and the vegetable crop, Washabii japonica has been cultivated.

\section{MATERIALS AND METHODS}

\section{Trapping procedure}

From April 1985 to October 1986, 36 Sherman live traps $(5.5 \mathrm{~cm} \times 6.5 \mathrm{~cm} \times 15.8 \mathrm{~cm})$ baited with sweet potato and peanut butter were set with 10 meter's trap spacing on a $6 \times 6$ grid for $4-5$ consecutive nights each month in Grids A and B. For the purpose of eliminating the edge effect, additional 24 traps were arranged 5-8 m apart from the surrounding trap-belts of the two grids at $10 \mathrm{~m}$ interval to cover a trapping area of 0.36 ha. The trapping session in Grid A was conducted until December 1987, where the grid was enlarged to 10 rows and 10 columns at $10 \mathrm{~m}$ intervals $(0.81 \mathrm{ha})$ with large Sherman traps $(8.5 \mathrm{~cm} \times 10.5 \mathrm{~cm} \times \mathbf{2 9 . 4} \mathrm{cm})$ in place of small traps from August 1988 to July 1989 (named Grid A' below): Grid A' was designed to determine more exactly spatial distribution and movements (Lin and Shiraishi, in press.). Capture efficiency of large Sherman traps is much the same as small ones for A. semotus (Lin and Lin, 1988).

Traps were checked every morning and evening. After trapped animals were marked by toe-clipping and weighed, sex and reproductive conditions (testicular descent, vaginal opening, pregnancy or lactation) were recorded, and they were immediately released at the points of capture.

\section{Population estimate}

Monthly population numbers were estimated by direct enumeration of the minimum number of mice known to be alive (Krebs, 1966). The technique gives reliable results if trappability (defined as the percentage of mice known to be alive that were actually captured during a given trapping period) is $50 \%$ or greater (Hilborn et al., 1976). The population density was converted into the number per hectare.

Demographic parameters such as survival rates per month (proportion of animals that survived until time $t+1$ to those present at time $t$; Chitty and Phipps, 1966), recruitment rates (percentage of new animals added to the trappable population either newly born or immigrants from surrounding areas) and sex ratios (percentage of males 

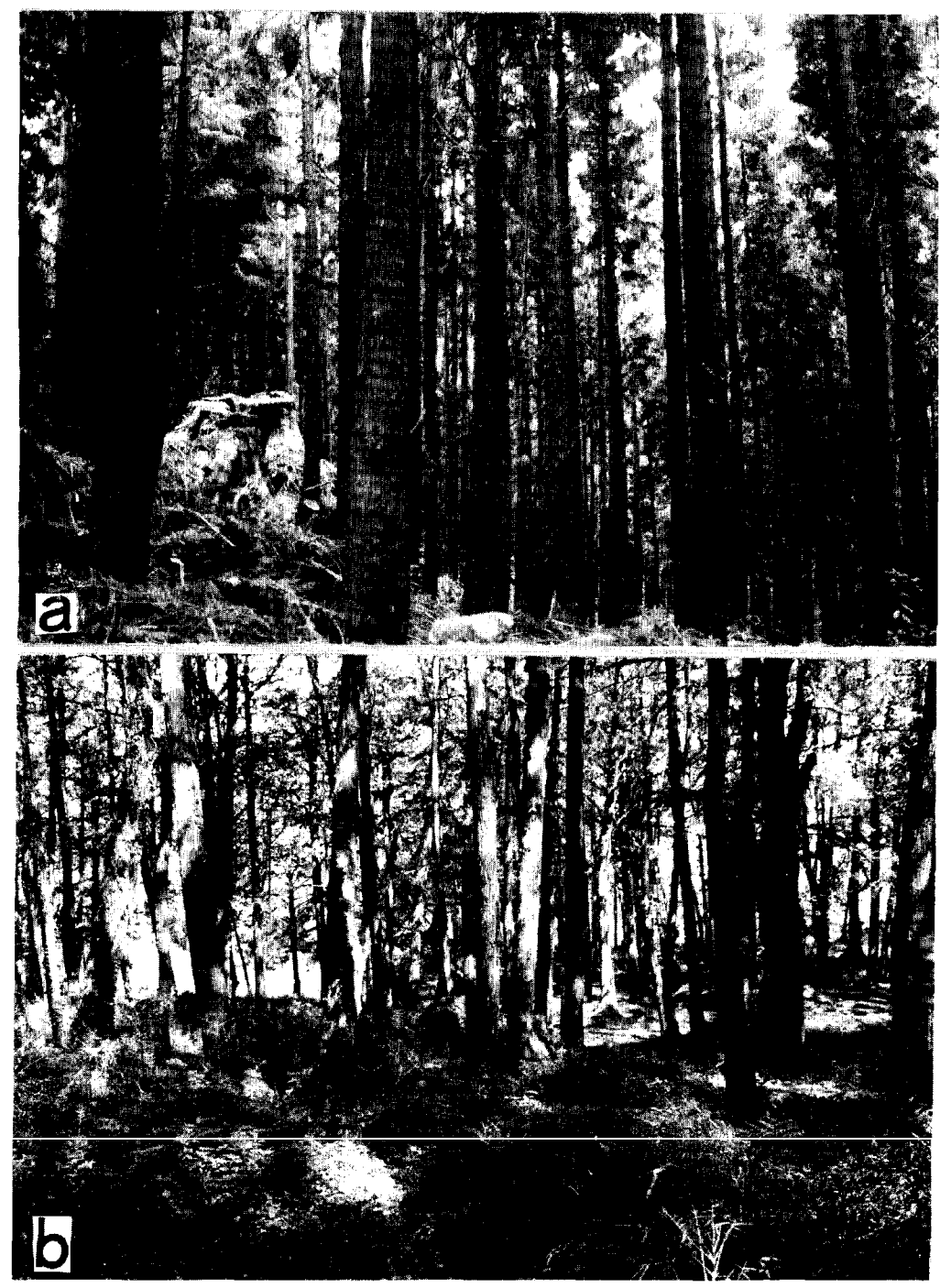

Fig. 1. Photographs showing the habitat of the study area. (a) Grids A and A'; (b) Grid B.

captured to the total number during the trapping period) were calculated, and body weight was measured according to different reproductive classes (in males, fully descended testes, descending testes, abdominal testes; in females, perforate or imperforate vagina).

\section{Food habit analysis}

Samples of stomach contents were taked from 8 adult males caught with snap traps baited with sweet potato in the areas adjacent to Grid A in February and August 
1988. The material was washed in a $0.2 \mathrm{~mm}$ mesh sieve and a subsample was mounted on a glass slide under a coverslip in Canada balsam. Three slides were made for each sample, examined with microscope and identified with the following broad categories: green plant material, fungi, seed and animal remains. As for Grids A and A', microscopic sections of leaves and fruits of dominant plant species (Polygonum chinense, Polygonum thunbergii and Hydrocotyle nepalensis) were prepared for reference. The relative area of different categories of each food in microscopical view was made as an estimate of the composition of the stomach contents by volume.

\section{RESULTS}

The results obtained by the mark-and-recapture method are summarized in Table 1. In every grid, A. semotus was most numerous among the small mammals captured. Overall trappability of this species was $92.4 \%$ in Grid A and $84.5 \%$ in Grid A', although in Grid B trap-death often occurred and consequently trappability was not calculated.

Table 1. Recapture records of small mammals at Alisan Alpine Forest Park

\begin{tabular}{lcccccc} 
& \multicolumn{2}{c}{ Grid A } & \multicolumn{2}{c}{ Grid A' } & \multicolumn{2}{c}{ Grid B } \\
\cline { 2 - 7 } Species & $\begin{array}{c}\text { No. of } \\
\text { individuals }\end{array}$ & $\begin{array}{c}\text { No. of } \\
\text { captures }\end{array}$ & $\begin{array}{c}\text { No. of } \\
\text { individuals }\end{array}$ & $\begin{array}{c}\text { No. of } \\
\text { captures }\end{array}$ & $\begin{array}{c}\text { No. of } \\
\text { individuals }\end{array}$ & $\begin{array}{c}\text { No. of } \\
\text { captures }\end{array}$ \\
\hline $\begin{array}{c}\text { A podemus } \\
\text { semotus }\end{array}$ & 287 & 825 & 171 & 862 & 147 & 436 \\
$\begin{array}{c}\text { Niviventer } \\
\text { culturatus }\end{array}$ & 36 & 78 & 17 & 88 & 4 & 9 \\
$\begin{array}{c}\text { Microtus } \\
\text { kikuchii }\end{array}$ & 4 & 4 & 3 & 4 & 2 & 2 \\
$\begin{array}{c}\text { Eothenomys } \\
\text { melanogaster }\end{array}$ & 16 & 25 & 22 & 66 & 22 & 32 \\
$\begin{array}{c}\text { Anourosorex } \\
\text { squamipes }\end{array}$ & 21 & 26 & 21 & 22 & 40 & 42 \\
$\begin{array}{c}\text { Soriculus } \\
\text { fumidus }\end{array}$ & 58 & 67 & 59 & 63 & 43 & 45 \\
Crocidura sp. & 5 & 5 & 13 & 13 & 4 & 4
\end{tabular}

\section{Population density}

Changes with the passage of time in A. semotus population density are presented in Table 2. In Grids A and A', seasonally conspicuous fluctuations of the population density were evident (Fig. 2a). The density began to increase in late spring, reached the maximum in August and declined from October to February. The general patterns of density change in successive four years were similar to one another, but variations in density and in timing of a peak of the annual cycle were noted, especially the low density in 1987. The population density in Grid B declined sharply in September without clear changes of the population density in January-August of 1985 and 1986 (Fig. 2b).

The highest densities were 66.7/ha and 56.8/ha in Grids A and A'(Cryptomeria plantation habitat), respectively, and 51.4/ha in Grid B (Chamaecyparis habitat), and the 
Table 2. Minimum numbers alive (MNA) and population densities in each grid in A podemus semotus.

\begin{tabular}{|c|c|c|c|c|c|c|c|c|}
\hline \multicolumn{3}{|c|}{ Grid A } & \multicolumn{3}{|c|}{ Grid A' } & \multicolumn{3}{|c|}{ Grid B } \\
\hline Month & MNA & $\begin{array}{l}\text { Density } \\
\text { (no./ha) }\end{array}$ & Month & MNA & $\begin{array}{l}\text { Density } \\
\text { (no./ha) }\end{array}$ & Month & MNA & $\begin{array}{l}\text { Density } \\
\text { (no./ha) }\end{array}$ \\
\hline 1985 & & & 1988 & & & 1985 & & \\
\hline Apr. & 15 & 41.7 & Aug. & 46 & 56.8 & Apr. & 18 & 51.4 \\
\hline May & 16 & 44.4 & Sep. & 44 & 54.3 & May & 13 & 37.1 \\
\hline Jun. & 16 & 44.4 & Oct. & 33 & 40.7 & Jun. & 15 & 42.9 \\
\hline Jul. & 15 & 41.7 & Nov. & 32 & 39.5 & Jul. & 12 & 34.3 \\
\hline Aug. & 19 & 52.8 & Dec. & 35 & 43.2 & Aug. & 16 & 45.7 \\
\hline Sep. & 20 & 55.6 & & & & Sep. & 7 & 20.0 \\
\hline Oct. & 7 & 19.4 & 1989 & & & Oct. & 2 & 5.7 \\
\hline Nov. & 13 & 36.1 & Jan. & 33 & 40.7 & Nov. & 10 & 28.6 \\
\hline \multirow[t]{2}{*}{ Dec. } & 12 & 33.3 & Feb. & 29 & 35.8 & Dec. & 10 & 28.6 \\
\hline & & & Mar. & 20 & 24.7 & & & \\
\hline 1986 & & & Apr. & 18 & 22.2 & 1986 & & \\
\hline Jan. & 18 & 50.0 & May & 34 & 42.0 & Jan. & 11 & 31.4 \\
\hline Feb. & 18 & 50.0 & Jun. & 32 & 39.5 & Feb. & 11 & 31.4 \\
\hline Mar. & 16 & 44.4 & Jul. & 35 & 43.2 & Mar. & 13 & 37.1 \\
\hline Apr. & 11 & 30.6 & & & & Apr. & 10 & 28.6 \\
\hline May & 15 & 41.7 & & & & May & 13 & 37.1 \\
\hline Jun. & 12 & 33.3 & & & & Jun. & 16 & 45.7 \\
\hline Jul. & 15 & 41.7 & & & & Jul. & 14 & 40.0 \\
\hline Aug. & 24 & 66.7 & & & & Aug. & 15 & 42.9 \\
\hline Sep. & 24 & 66.7 & & & & Sep. & 6 & 17.1 \\
\hline Oct. & 21 & 58.3 & & & & Oct. & 8 & 22.9 \\
\hline Nov. & 18 & 50.0 & & & & & & \\
\hline Dec. & 6 & 16.7 & & & & & & \\
\hline \multicolumn{9}{|l|}{1987} \\
\hline Jan. & 10 & 27.8 & & & & & & \\
\hline Feb. & 5 & 13.9 & & & & & & \\
\hline Mar. & 4 & 11.1 & & & & & & \\
\hline Apr. & 5 & 13.9 & & & & & & \\
\hline May & 7 & 19.4 & & & & & & \\
\hline Jun. & 4 & 11.1 & & & & & & \\
\hline Jul. & 8 & 22.2 & & & & & & \\
\hline Aug. & 13 & 36.1 & & & & & & \\
\hline Sep. & 7 & 19.4 & & & & & & \\
\hline Oct. & 4 & 11.1 & & & & & & \\
\hline Nov. & 8 & 22.2 & & & & & & \\
\hline Dec. & 8 & 22.2 & & & & & & \\
\hline
\end{tabular}

lowest densities were 11.1/ ha and 22.2/ha in Grids A and A', respectively, and 5.7/ ha in Grid B. As for the density relating to grid sizes, there was no significant difference between Grids $\mathrm{A}$ and $\mathrm{A}^{\prime}(t=1.06, P>0.05)$. The population density in Cryptomeria plantation habitat seemed higher than in the Chamaecyparis habitat; however, the mean values in the above two habitats were not significantly different $(t=0.83, P>0.05)$.

\section{Sex ratio}

Since sex ratios were computed by separately summing males and females known 
to be alive over every trapping period, an individual mouse might be included several times. The male: female ratio based on livetrapping data from all grids was $1.63(62.0 \%$ for males, $\left.\chi^{2}=63.19, P<0.001\right)$. The sex ratios according to seasons were characterized by significantly more males than females, except in summer of 1987 in Grid A and in summer of 1985 in Grid B: the proportion of males declined slightly in summer as a whole (Table 3). The high variability of sex ratio in Grid A with the lowest density during 1987 might be closely related to the great instability of this population in the year.

\section{Survival and duration of residence}

Survival rates per month for sexes are shown in Table 4. Means ( \pm S.D.) of the survival rates were $0.39 \pm 0.24$ for males and $0.31 \pm 0.33$ for females in Grid A, $0.66 \pm$ 0.17 for males and $0.60 \pm 0.22$ for females in Grid $A^{\prime}$ and $0.28 \pm 0.19$ for males and $0.36 \pm 0.33$ for females in Grid B. In general, the survival rates were higher in the Cryptomeria plantation habitat (Grids $\mathrm{A}$ and $\mathrm{A}^{\prime}$ ) than in the Chamaecyparis habitat (Grid B). In Grid A', no significant correlations were found between the monthly

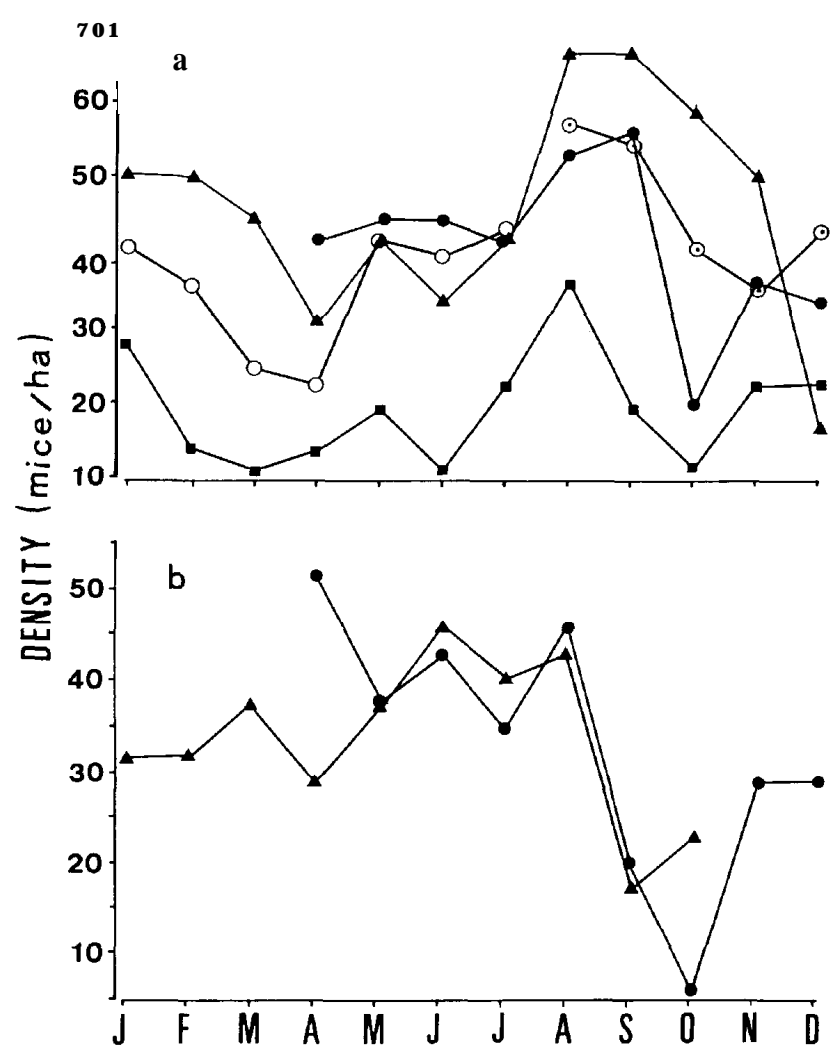

Fig. 2. Changes of the density in Apodemus semotus. (a) Grids A and A'; (b) Grid B. - 1985 (Grids A and B); $\longrightarrow, 1986$ (Grids A and B); H, 1987 (Grid A), $\odot \multimap, 1988$ (Grid A'); ○- 0,1989 (Grid A'). 
survival rates (Table 4) and the density values for the next month (Table 2) $(r=$ $-0.368, P>0.05$ in males; $r=-0.024, P>0.05$ in females), whereas the female survival rates in Grid A showed a significant correlation with the density values $(r=$ $0.534, P<0.001)$ and the male survival rates in Grid B were significantly correlated with the densities $(r=0.581, P<0.05)$. The monthly survival rates were generally low and highly variable in Grid A during 1987, whereas higher survival rates occurred in Grid A' in 1989, especially in April (Fig. 3a). In Grids A and A', there was a tendency for the survival rates to increase in late summer and to decrease sharply in autumn; however, survival was improved again in winter (Fig. 3a). In Grid B, the patterns of the survival in 1985-1986 were similar to each other, with good survival in late spring and a sharp decrease in late summer or autumn (Fig. 3b).

In Grid A, 54.5\% of individuals stayed for only one month and the maximal length of residence reached eight months during the period from April 1985 to December 1987. In Grid A', only one male and one female $(0.8 \%)$ were found in residence for one year, but 4 males and 5 females $(3.8 \%)$ were captured in the grid after five months (Fig. 4). Trapping was not attempted in Grid A from January to July 1988, but was resumed in Grid A' in August 1988 when Grid A was enlarged in area; however, animals released

Table 3. Seasonal variation in the sex ratio of A podemus

semotus (percentage of males to the total MNA)*.

\begin{tabular}{|c|c|c|c|c|c|}
\hline \multirow{2}{*}{ Grid } & \multirow{2}{*}{ Year } & \multicolumn{4}{|c|}{$\begin{array}{c}\text { Sex ratio } \\
\left(\sigma^{\pi}, \text { 우 }\right)\end{array}$} \\
\hline & & Spring & Summer & Autumn & Winter \\
\hline \multirow[t]{6}{*}{ A } & 1985 & 64.5 & 64.0 & 70.0 & 58.3 \\
\hline & & $(20,11)$ & $(32,18)$ & $(28,12)$ & $(28,20)$ \\
\hline & 1986 & 52.4 & 60.8 & 65.1 & 81.0 \\
\hline & & $(22,20)$ & $(31,20)$ & $(41,22)$ & $(17,4)$ \\
\hline & 1987 & 68.8 & 44.0 & 68.4 & 75.0 \\
\hline & & $(11,5)$ & $(11,14)$ & $(13,6)$ & $(6, \quad 2)$ \\
\hline \multirow[t]{4}{*}{$A^{\prime}$} & 1988 & & 60.9 & 62.4 & 62.9 \\
\hline & & & $(28,18)$ & $(68,41)$ & $(61,36)$ \\
\hline & 1989 & 69.4 & 55.2 & & - \\
\hline & & $(50,22)$ & $(37,30)$ & & \\
\hline \multirow[t]{3}{*}{ B } & 1985 & 64.5 & 48.8 & 73.7 & 62.5 \\
\hline & & $(20,11)$ & $(21,22)$ & $(14,5)$ & $(20,12)$ \\
\hline & 1986 & $\begin{array}{c}61.1 \\
(22,14)\end{array}$ & $\begin{array}{c}55.6 \\
(25,20)\end{array}$ & $\begin{array}{c}71.4 \\
(10, \quad 4)\end{array}$ & - \\
\hline \multirow{2}{*}{\multicolumn{2}{|c|}{ Total }} & 63.6 & 56.6 & 65.9 & 64.1 \\
\hline & & $(145,83)$ & $(185,142)$ & $(174,90)$ & $(132,74)$ \\
\hline
\end{tabular}

*Four seasons are defined as follows: Spring, March to May; Summer, June to August; Autumn, September to November; Winter, December to February. In Grid A, the data in spring of 1985 include only April and May and those in winter of 1987 do December alone. In Grid A', the data in summer of 1988 include August alone and those in summer of 1989 do only June and July. In Grid B, the data in spring of 1985 contain only April and May and those in autumn of 1986 contain only September and October. 
Table 4. Survival rates per month in Apodemus semotus.

\begin{tabular}{|c|c|c|c|c|c|c|c|c|c|c|c|}
\hline \multicolumn{4}{|c|}{ Grid A } & \multicolumn{4}{|c|}{ Grid A' } & \multicolumn{4}{|c|}{ Grid B' } \\
\hline Month & Male & Female & $\begin{array}{l}\text { en } \\
\text { bloc }\end{array}$ & Month & Male & Female & $\begin{array}{l}\text { en } \\
\text { bloc }\end{array}$ & Month & Male & Female & $\begin{array}{l}\text { en } \\
b l o c\end{array}$ \\
\hline 1985 & & & & 1988 & & & & 1985 & & & \\
\hline Apr. & 0.38 & 0.75 & 0.50 & Aug. & 0.54 & 0.71 & 0.60 & Apr. & 0.20 & 0.50 & 0.29 \\
\hline May & 0.45 & 0.50 & 0.47 & Sep. & 0.70 & 0.41 & 0.57 & May & 0.50 & 0.50 & 0.50 \\
\hline Jun. & 0.33 & 0.50 & 0.40 & Oct. & 0.56 & 0.50 & 0.54 & Jun. & 0.50 & 0.25 & 0.33 \\
\hline Jul. & 0.67 & 0.40 & 0.57 & Nov. & 0.35 & 0.20 & 0.32 & Jul. & 0.33 & 0.33 & 0.33 \\
\hline Aug. & 0.42 & 0.43 & 0.42 & Dec. & 0.68 & 0.73 & 0.70 & Aug. & 0.17 & 0.50 & 0.30 \\
\hline Sep. & 0.50 & 0.20 & 0.38 & & & & & Sep. & 0.00 & 0.00 & 0.00 \\
\hline Oct. & 0.00 & 0.00 & 0.00 & 1989 & & & & Oct. & 0.00 & 0.00 & 0.00 \\
\hline Nov. & 0.45 & 0.00 & 0.36 & Jan. & 0.75 & 0.71 & 0.74 & Nov. & . 0.43 & 0.00 & 0.33 \\
\hline Dec. & 0.71 & 0.40 & 0.58 & Feb. & 0.77 & 70.44 & 0.64 & Dec. & 0.20 & 1.00 & 0.33 \\
\hline & & & & Mar. & 0.75 & 0.80 & 0.76 & & & & \\
\hline 1986 & & & & Apr. & 1.00 & 1.00 & 1.00 & 1986 & & & \\
\hline Jan. & 0.36 & 0.75 & 0.47 & May & 0.50 & 0.50 & 0.50 & Jan. & 0.40 & 0.00 & 0.33 \\
\hline Feb. & 0.25 & 1.00 & 0.54 & Jun. & 0.63 & 0.57 & 0.60 & Feb. & 0.25 & 0.00 & 0.17 \\
\hline Mar. & 0.71 & 0.00 & 0.36 & & & & & Mar. & 0.33 & 0.17 & 0.25 \\
\hline Apr. & 0.43 & 0.33 & 0.50 & & & & & Apr. & 0.00 & 1.00 & 0.33 \\
\hline May & 0.50 & 0.33 & 0.46 & & & & & May & 0.71 & 0.50 & 0.67 \\
\hline Jun. & 0.67 & 0.00 & 0.45 & & & & & Jun. & 0.38 & 0.75 & 0.50 \\
\hline Jul. & 0.78 & 0.40 & 0.64 & & & & & Jul. & 0.29 & 0.20 & 0.25 \\
\hline Aug. & 0.50 & 0.56 & 0.52 & & & & & Aug. & 0.10 & 0.25 & 0.14 \\
\hline Sep. & 0.69 & 0.75 & 0.71 & & & & & Sep. & 0.25 & 0.50 & 0.33 \\
\hline Oct. & 0.47 & 0.43 & 0.46 & & & & & & & & \\
\hline Nov. & 0.15 & 0.00 & 0.19 & & & & & & & & \\
\hline Dec. & 0.11 & 1.00 & 0.20 & & & & & & & & \\
\hline \multicolumn{12}{|l|}{1987} \\
\hline Jan. & 0.33 & 0.00 & 0.25 & & & & & & & & \\
\hline Feb. & 0.50 & 0.00 & 0.50 & & & & & & & & \\
\hline Mar. & 0.67 & 0.00 & 0.40 & & & & & & & & \\
\hline Apr. & 0.00 & 0.00 & 0.00 & & & & & & & & \\
\hline May & 0.40 & 0.00 & 0.33 & & & & & & & & \\
\hline Jun. & 0.00 & 0.00 & 0.00 & & & & & & & & \\
\hline Jul. & 0.00 & 0.75 & 0.43 & & & & & & & & \\
\hline Aug. & 0.25 & 0.38 & 0.31 & & & & & & & & \\
\hline Sep. & 0.00 & 0.00 & 0.00 & & & & & & & & \\
\hline Oct. & 0.25 & 0.00 & 0.20 & & & & & & & & \\
\hline Nov. & 0.57 & 0.00 & 0.44 & & & & & & & & \\
\hline Dec. & 1.00 & 1.00 & 1.00 & & & & & & & & \\
\hline
\end{tabular}

by December 1987 in Grid A were not recaptured at the beginning of the subsequent trapping. This indicates that those animals may disperse or die during eight months. In Grid B, $58.0 \%$ of individuals stayed for only one month, and residence of the remains did not exceed five months at longest (Fig. 4).

\section{Recruitment rates and number of transients}

The overall recruitment rate in every grid increased at the end of the reproductive period (late spring to summer and late fall to winter) (Table 5), which resulted from mainly recruitment of juveniles into the population (Fig. 5). The dynamics of recruit- 


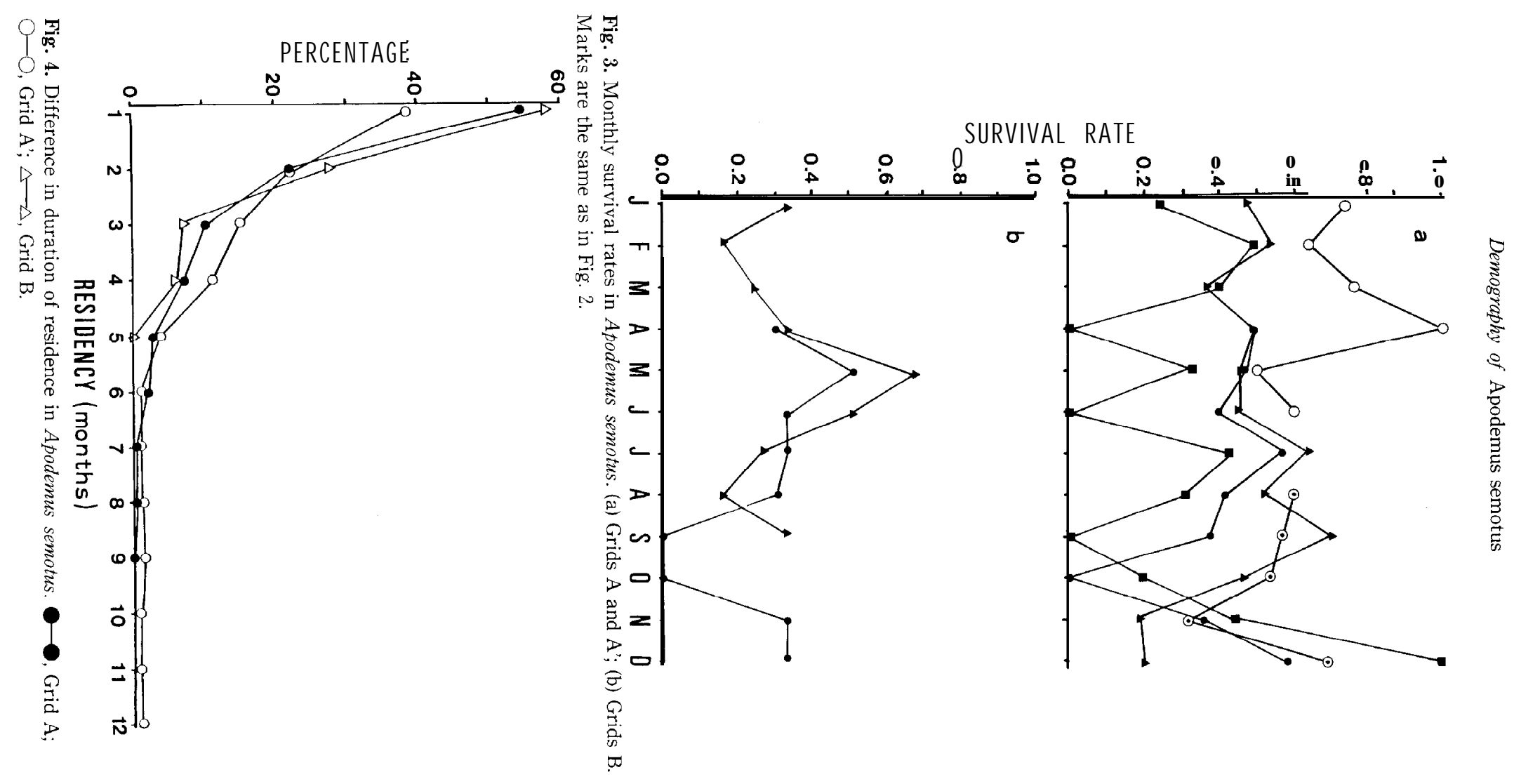


ment in Grid A had a similar tendency during the period from 1986 to 1987, except for October (Fig. 5a). The lowest yearly recruitment rate in Grid A' was found in JanuaryApril (26.9\%-29.8\%) and October (23.1\%) (Fig. 5a). Grid B $(69.2 \pm 18.3 \%$ ) had higher recruitment rates than did Grids A $(64.9 \pm 15.3 \%)$ and $\mathrm{A}^{\prime}(39.9 \pm 14.5 \%)$ (Fig. 5b). No significant correlations were found between the monthly overall recruitment rates and the density values (cf. Table 2$)$ in every grid $(r=-0.364, P>0.05$ in Grid A; $r=$ $0.335, P>0.05$ in Grid A'; $r=-0.326, P>0.05$ in Grid B). In general, more males than females joined the population in every gird, except for adults in Grid A' (Chi-square test, $P<0.05$ ) and for juveniles in Grid B (Chi-square test, $P<0.05$ ) (Table 6).

Table 5. Monthly overall recruitment rates (percentages of new animals to total captured numbers) and juvenile recruitment rates (percentages of juveniles to new animals) in each grid in Apodemus semotus.

\begin{tabular}{|c|c|c|c|c|c|c|c|c|}
\hline \multicolumn{3}{|c|}{ Grid A } & \multicolumn{3}{|c|}{ Grid A' } & \multicolumn{3}{|c|}{ Grid B } \\
\hline Month & Overall & Juvenile & Month & Overall & Juvenile & Month & Overall & Juvenile \\
\hline 1985 & & & 1988 & & & 1985 & & \\
\hline May & 66.7 & 41.7 & Sep. & 37.8 & 21.4 & May & 69.2 & 77.8 \\
\hline Jun. & 52.9 & 44.4 & Oct. & 23.1 & 66.7 & Jun. & 66.7 & 60.0 \\
\hline Jul. & 46.7 & 28.6 & Nov. & 57.7 & 80.0 & Jul. & 41.7 & 20.0 \\
\hline Aug. & 63.6 & 35.7 & Dec. & 61.3 & 73.6 & Aug. & 56.3 & 0 \\
\hline Sep. & 61.9 & 15.4 & & & & Sep. & 71.4 & 0 \\
\hline Oct. & 66.7 & 0 & 1989 & & & Oct. & 100.0 & 0 \\
\hline Nov. & 81.3 & 30.8 & Jan. & 26.9 & 42.9 & Nov. & 90.0 & 0 \\
\hline Dec. & 41.7 & 80.0 & $\begin{array}{l}\text { Feb. } \\
\text { Mar. }\end{array}$ & $\begin{array}{l}26.9 \\
29.4\end{array}$ & $\begin{array}{c}0 \\
20.0\end{array}$ & Dec. & 90.0 & 55.6 \\
\hline 1986 & & & Apr. & 28.6 & 50.0 & 1986 & & \\
\hline Jan. & 65.0 & 69.2 & May & 58.1 & 55.6 & Jan. & 63.6 & 42.9 \\
\hline Feb. & 60.0 & 0 & Jun. & 51.5 & 41.2 & Feb. & 63.6 & 28.6 \\
\hline Mar. & 76.5 & 0 & Jul. & 37.1 & 69.3 & Mar. & 92.3 & 16.7 \\
\hline Apr. & 53.8 & 42.9 & & & & Apr. & 70.0 & 0 \\
\hline May & 76.2 & 25.0 & & & & May & 84.6 & 27.3 \\
\hline Jun. & 57.1 & 12.5 & & & & Jun. & 56.3 & 44.4 \\
\hline Jul. & 75.0 & 50.0 & & & & Jul. & 50.0 & 28.6 \\
\hline Aug. & 68.2 & 0 & & & & Aug. & 53.3 & 50.0 \\
\hline Sep. & 44.0 & 36.4 & & & & Sep. & 33.3 & 0 \\
\hline Oct. & 36.0 & 44.4 & & & & Oct. & 75.0 & 0 \\
\hline Nov. & 52.4 & 45.5 & & & & & & \\
\hline Dec. & 50.0 & 100.0 & & & & & & \\
\hline \multicolumn{9}{|l|}{1987} \\
\hline Jan. & 72.7 & 25.0 & & & & & & \\
\hline Feb. & 60.0 & 0 & & & & & & \\
\hline Mar. & 85.7 & 33.3 & & & & & & \\
\hline Apr. & 60.0 & 0 & & & & & & \\
\hline May & 71.4 & 60.0 & & & & & & \\
\hline Jun. & 66.7 & 50.0 & & & & & & \\
\hline Jul. & 77.8 & 42.9 & & & & & & \\
\hline Aug. & 75.0 & 16.7 & & & & & & \\
\hline Sep. & 37.5 & 66.7 & & & & & & \\
\hline Oct. & 100.0 & 20.0 & & & & & & \\
\hline Nov. & 88.9 & 62.5 & & & & & & \\
\hline Dec. & 83.3 & 60.0 & & & & & & \\
\hline
\end{tabular}




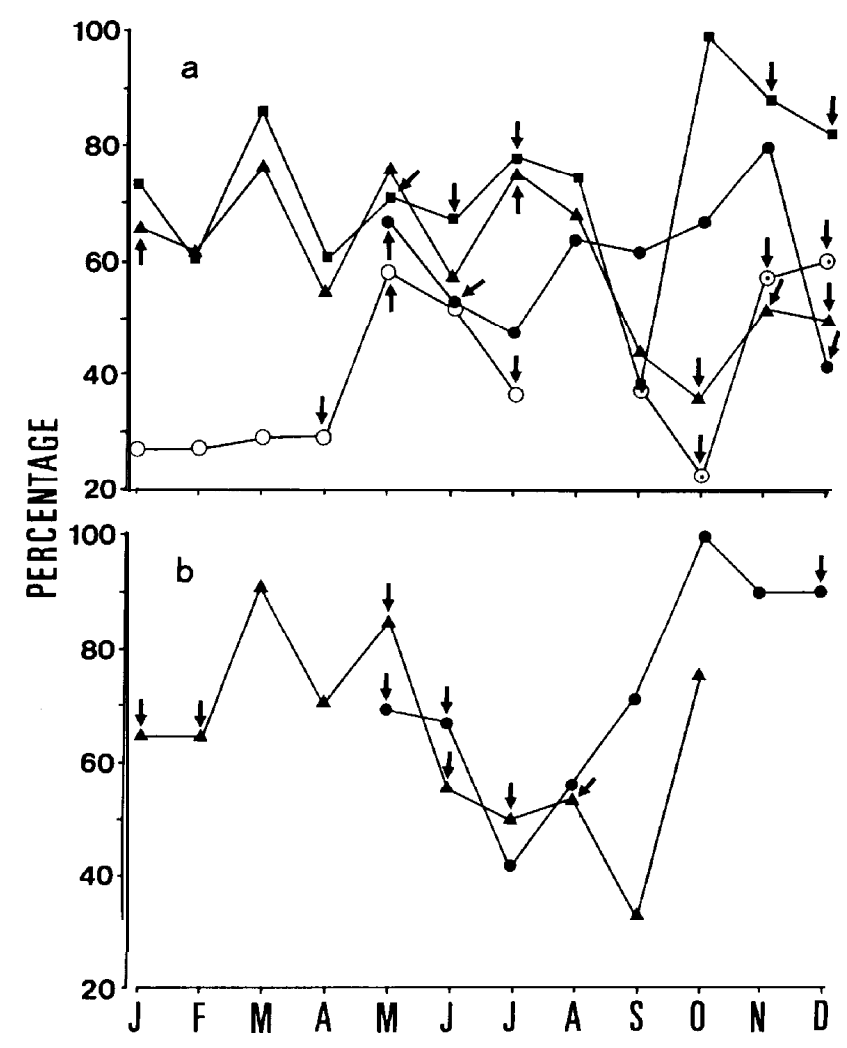

Fig. 5. Monthly overall recruitment rates in Apodemus semotus. (a) Grids A and A'; (b) Grid B. Marks are the same as in Fig. 2. At the time indicated by an arrow, the monthly recruitment rates of juveniles (cf. Table 5) are higher than the following mean values of the recruitment rates of juveniles (37\% in Grid A; $47 \%$ in Grid A'; $25 \%$ in Grid B).

Table 6. Number of recruits in each grid in Apodemus semotus.

\begin{tabular}{|c|c|c|c|c|c|c|}
\hline \multirow{2}{*}{ Grid } & \multicolumn{2}{|c|}{ A } & \multicolumn{2}{|c|}{$A^{\prime}$} & \multicolumn{2}{|c|}{ B } \\
\hline & Male & Female & Male & Female & Male & Female \\
\hline \multicolumn{7}{|l|}{ Adult } \\
\hline Captured no. & 118 & 67 & 31 & 29 & 82 & 47 \\
\hline $\begin{array}{l}\text { Expected value* } \\
\text { Juvenile }\end{array}$ & 114.7 & 70.3 & 37.2 & 22.8 & 80.0 & 49.0 \\
\hline Captured no. & 57 & 35 & 42 & 23 & 21 & 21 \\
\hline Expected value* & 57.1 & 35.0 & 40.3 & 24.7 & 26.0 & 16.0 \\
\hline
\end{tabular}

*Estimated by the sex ratio ( $\sigma^{7} 1.63:$ 우 1$)$ 
In this study, animals captured only during one monthly trapping session were considered as transients. Among proportions of adult transients by sexes to the total number of individuals in Grids $\mathrm{A}, \mathrm{A}^{\prime}$ and $\mathrm{B}$, those of both male and female transients in Grid $A^{\prime}$ represented the lowest for respective sexes. In juveniles, on the other hand, male transients in Grid B and female transients in Grid A had the lowest proportion for each sex (Table 7). In Grid A and B, the majority of the transients might be influenced by the striking edge effect owing to narrow trapping areas. Thus, the data only from Grid A' were analyzed for the correlation between the proprtions of transients and the density values: in the case, only the adult male transient showed a

Table 7. Proportion of transients in each grid in Apodemus semotus.

\begin{tabular}{|c|c|c|c|c|c|c|}
\hline & \multicolumn{2}{|c|}{ Grid A } & \multicolumn{2}{|c|}{ Grid A' } & \multicolumn{2}{|c|}{ Grid B' } \\
\hline & 9 & 우 & $0^{x}$ & 우 & क & 우 \\
\hline Juvenile & 0.51 & 0.47 & 0.43 & 0.50 & 0.40 & 0.58 \\
\hline Adult & 0.56 & 0.60 & 0.43 & 0.29 & 0.67 & 0.48 \\
\hline
\end{tabular}

Table 8. Percentages of males and females according to reproductive classes in Apodemus semotus.

\begin{tabular}{cccccc}
\multicolumn{3}{c}{ Male } & \multicolumn{3}{c}{ Female } \\
\hline t.s. & t.d. & t.a. & v.p. & 1. & v.i.
\end{tabular}

Grid A 1985

A p r. $100.0(10) 0.0(0) 0.0(0)$

$\mathrm{M}$ a y $83.3(10) 0.0(0) 16.7(2)$

Jun. $72.7(8) \quad 9.1(1) 18.2(2)$

Jul. $\quad 50.0(5) \quad 50.0(5) \quad 0.0(0)$

$\mathrm{A} \mathrm{u} \mathrm{g} \mathrm{.} \mathrm{93.3(14)} \mathrm{6.7(1)} 0.0(0)$

Sep. $\quad 85.7(12) \quad 0.0(0) \quad 14.3(2)$

Oct. $\quad 66.7(2) \quad 33.3(1) \quad 0.0(0)$

$\mathrm{N}$ o v . 58.3(7) 16.7(2) 25.0(3)

Dec. $\quad 42.9(3) \quad 14.2(2) \quad 42.9(3)$ 1986

$\begin{array}{llll}\text { Jan. } & 25.0(3) & 16.7(2) & 58.3(7)\end{array}$

Feb. $\quad 84.6(11) \quad 15.4(2) \quad 0.0(0)$

Mar. $100.0(8) \quad 0.0(0) \quad 0.0(0)$

Apr. $\quad 77.8(7) \quad 0.0(0) 22.2(2)$

M a y $69.2(9) \quad 7.7(1) 23.1(3)$

$\mathrm{J} \mathrm{u} \mathrm{n} \mathrm{.} \mathrm{60.0(6)} 30.0(3) 10.0(1)$

Jul. $\quad 60.0(6) \quad 10.0(1) \quad 30.0(3)$

A u g . 100.0(12) $0.0(0) 0.0(0)$

$\begin{array}{llll}\text { Sep. } & 81.3(13) & 0.0(0) & 18.7(3)\end{array}$

Oct. $\quad 55.6(10) 11.1(2) 33.3(6)$

$\mathrm{N}$ o v . 40.0(6) 20.0(3) 40.0(6)

Dec. $\quad 81.2(9) \quad 18.8(2) \quad 0.0(0)$ 1987

J a n. $75.0(6) \quad 0.0(0) 25.0(2)$

Feb. $100.0(5) \quad 0.0(0) \quad 0.0(0)$

M a r . 50.0(2) 25.0(1) 26.0(1)

Apr. $100.0(5) \quad 0.0(0) \quad 0.0(0)$
$20.0(1) \quad 60.0(3) \quad 20.0(1)$

$0.0(0) \quad 50.0(3) \quad 50.0(3)$

$16.7(1) \quad 33.3(2) \quad 50.0(3)$

$20.0(1) \quad 40.0(2) \quad 40.0(2)$

$14.3(1) \quad 42.9(3) \quad 42.9(3)$

$14.3(1) \quad 57.1(4) \quad 14.3(1)$

$\begin{array}{rrr}0.0(0) & 0.0(0) & 0.0(0)\end{array}$

$0.0(0) \quad 75.0(3) \quad 25.0(1)$

$20.0(1) \quad 20.0(1) \quad 60.0(3)$

$50.0(4) \quad 125(1) \quad 37.5(3)$

$71.4(5) 286(2) \quad 0.0(0)$

$22.2(2) \quad 778(7) \quad 0.0(0)$

$0.0(0) 75 \quad O(3) 25.0(1)$

$12.5(1) \quad 625(5) \quad 25.0(2)$

$0.0(0) 1000(4) \quad 0.0(0)$

$33.3(2) \quad 167(1) \quad 50.0(3)$

$70.0(7) \quad 300(3) \quad 0.0(0)$

$44.4(4) 44 \quad 4(4) \quad 22.2(1)$

$\begin{array}{llll}57.1(4) & 42 & 9(3) & 0.0(0)\end{array}$

$33.3(2) \quad 50 \quad O(3) \quad 16.7(1)$

$0.0(0) \quad 0 \quad 0(0) 100.0(1)$

$67.2(2) \quad 33.3(1) \quad 0.0(0)$

$\begin{array}{lll}0.0(0) & 0.0(0) & 0.0(0)\end{array}$

$100.0(3) \quad 0.0(0) \quad 0.0(0)$

$\begin{array}{lll}0.0(0) & 0.0(0) & 0.0(0)\end{array}$ 
(continued)

\begin{tabular}{|c|c|c|c|c|c|c|}
\hline May & $40.0(2)$ & $20.0(1)$ & $40.0(2)$ & $0.0(0)$ & $0.0(0)$ & $100.0(1$ \\
\hline Jun. & $50.0(1)$ & $0.0(0)$ & $50.0(1)$ & $0.0(0)$ & $0.0(0)$ & $100.0<1$ \\
\hline Jul. & $75.0(3)$ & $25.0(1)$ & $0.0(0)$ & $20.0(1)$ & $20.0(1)$ & $60.0(3$ \\
\hline Aug. & $87.5(7)$ & $0.0(0)$ & $12.5(1)$ & $50.0(4)$ & $37.5(3)$ & $12.5(1)$ \\
\hline Sep. & $75.0(3)$ & $0.0(0)$ & $25.0(1)$ & $25.0(1)$ & $50.0(2)$ & $25.0(1)$ \\
\hline Oct. & $75.0(3)$ & $25.0(1)$ & $0.0(0)$ & $100.0(1)$ & $0.0(0)$ & $0.0<0$ \\
\hline Nov. & $28.6(2)$ & $14.3(1)$ & $57.1(4)$ & $0.0(0)$ & $0.0(0)$ & $100.0<2$ \\
\hline Dec. & $0.0(0)$ & $25.0(1)$ & $75.0(3)$ & $0.0(0)$ & $50.0(1)$ & $50.0(1$ \\
\hline \multicolumn{7}{|l|}{ Grid A'1988 } \\
\hline Aug. & $78.6(22)$ & $10.7(3)$ & $10.7(3)$ & $44.4(8)$ & $27.8(5)$ & $27.8(5$ \\
\hline Sep. & $50.0(10)$ & $30.0(6)$ & $40.0(4)$ & $29.4(5)$ & $64.7(11)$ & ) $5.9(1$ \\
\hline Oct. & $50.0(8)$ & $25.0(4)$ & $25.0(4)$ & $20.0(2)$ & $50.0(5)$ & $30.0(3$ \\
\hline Nov. & $26.3(5)$ & $26.3(5)$ & $47.4(9)$ & $0.0(0)$ & $42.9(3)$ & $57.1(4$ \\
\hline Dec. & $10.0(2)$ & $20.0(4)$ & $70.0(14)$ & $27.3(3)$ & $18.2(2)$ & $54.5(6$ \\
\hline \multicolumn{7}{|c|}{ - } \\
\hline Jan. & $70.6(12)$ & $0.0(0)$ & $29.4(5)$ & $0.0(0)$ & $0.0(0)$ & $100.0(1$ \\
\hline Feb. & $81.3(13)$ & $18.7(3)$ & $0.0(0)$ & $80.8(8)$ & $20.0(2)$ & 0.060 \\
\hline Mar. & $72.7(8)$ & $18.2(2)$ & $9.1(1)$ & $33.3(2)$ & $33.3(2)$ & $33.3(2)$ \\
\hline Apr. & $100.0(9)$ & $0.0(0)$ & $0.0(0)$ & $75.0(3)$ & $25.0(1)$ & $0.0<0$ \\
\hline May & $35.0(7)$ & $35.0(7)$ & $30.0(6)$ & $36.4(4)$ & $27.3(3)$ & $36.3(4)$ \\
\hline Jun. & $55.6(10)$ & $11.1(2)$ & $33.3(6)$ & $50.0(7)$ & $28.6(4)$ & $21.4(3)$ \\
\hline Jul. & $57.9(11)$ & $15.8(3)$ & $26.3(5)$ & $37.5(6)$ & $37.5(6)$ & $25.0(4)$ \\
\hline \multicolumn{7}{|l|}{ Grid B 1985} \\
\hline Apr. & $83.4(10)$ & $8.3(1)$ & $8.3(1)$ & $50.0(3)$ & $16.7(1)$ & $33.3(2$ \\
\hline May & $25.0(2)$ & $0.0(0)$ & $75.0(6)$ & $20.0(1)$ & $20.0(1)$ & $60.0(3)$ \\
\hline Jun. & $12.5(1)$ & $37.5(3)$ & $50.0(4)$ & $28.6(2)$ & $0.0(0)$ & $71.4(5)$ \\
\hline Jul. & $25.0(1)$ & $75.0(3)$ & $0.0(0)$ & $25.0(2)$ & $25.0(2)$ & $50.0(4)$ \\
\hline Aug. & $100.0(9)$ & $0.0(0)$ & $0.0(0)$ & $100.0(7)$ & $0.0(0)$ & $0.0(0)$ \\
\hline Sep. & $100.0(5)$ & $0.0(0)$ & $0.0(0)$ & $100.0(2)$ & $0.0(0)$ & $0.0(0)$ \\
\hline Oct. & $100.0(1)$ & $0.0(0)$ & $0.0(0)$ & $100.0(1)$ & $0.0(0)$ & $0.0(0)$ \\
\hline Nov. & $75.0(6)$ & $25.0(2)$ & $0.0(0)$ & $100.0(2)$ & $0.0(0)$ & $0.0(0)$ \\
\hline Dec. & $0.0(0)$ & $50.0(3)$ & $50.0(3)$ & $25.0(1)$ & $0.0(0)$ & $75.0(3)$ \\
\hline \multicolumn{7}{|c|}{ 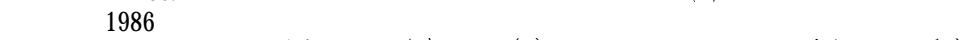 } \\
\hline Jan. & $33.3(2)$ & $33.3(2)$ & $33.3(2)$ & $60.0(3)$ & $0.0(0)$ & $40.0(2)$ \\
\hline Feb. & $62.5(5)$ & $25.0(2)$ & $12.5(1)$ & $33.3(1)$ & $0.0(0)$ & $66.7(2)$ \\
\hline Mar. & $100.0(6)$ & $0.0(0)$ & $0.0(0)$ & $57.1(4)$ & $14.3(1)$ & $28.6(2)$ \\
\hline Apr. & $100.0(6)$ & $0.0(0)$ & $0.0(0)$ & $100.0(4)$ & $0.0(0)$ & $0.0(0)$ \\
\hline May & $66.7(6)$ & $11.1(1)$ & $22.2(2)$ & $50.0(2)$ & $25.0(1)$ & $25.0(1)$ \\
\hline Jun. & $42.9(3)$ & $14.2(1)$ & $42.9(3)$ & $44.4(4)$ & $22.2(2)$ & $33.3(3)$ \\
\hline Jul. & $42.9(3)$ & $42.9(3)$ & $14.2(1)$ & $62.5(5)$ & $12.5(1)$ & $25.0(2)$ \\
\hline Aug. & $77.8(8)$ & $0.0(0)$ & $22.2(2)$ & $66.7(4)$ & $0.0(0)$ & $33.3(2)$ \\
\hline Sep. & 100.0 & $0.0(0)$ & $0.0(0)$ & $50.0(1)$ & $0.0(0)$ & $50.0(1)$ \\
\hline Oct. & $50.0(3)$ & $0.0(0)$ & $50.0(3)$ & $0.0(0)$ & $0.0(0)$ & $100.0(2)$ \\
\hline
\end{tabular}

t.s. = testes scrotal, t.d. = testes descending, t.a. = testes abdominal,

v.p. = vagina perforate, $1 .=$ lactating, v.i. = vagina imperforate .

Numerals in parentheses represent the number of captured individuals.

significant correlation with the density value $(r=0.679, P<0.05)$.

\section{Breeding season and body weights}

The reproductive condition of mice captured during the survey period is summarized in Table 8. Although some individuals were in reproductive condition throughout the year, breeding was strongly seasonal. In the present study, the breeding season is defined as that period when $50 \%$ or more of the males and females were in breeding 
condition. Males with fully descended testes had two considerable peaks (April and August) in all grids. Although females were too few to provide an accurate assessment of the breeding season, they were reproductively most active in late spring and autumn when the many were lactating.

In Grid A, the peak in reproductively active males came one month earlier in March only in 1986, and $100 \%$ of the females caught in five months (February, March, June, August and October) had perforated vaginal orifice. It is worthy of note that more juvenile males (17) than juvenile females (3) were caught from August in 1986 to January in 1987. In Grid A', relatively high proportions of pubertal males with descending testes appeared in both September 1988 and May 1989, being preceded by high proportions of reproductively active males with fully descended testes in August and April of respective years. In Grid B, the proportions of lactating females were relatively low during the period from April 1985 to October 1986.

Details of changes in body weight according to differnt reproductive classes are

Table 9. Mean body weight in grammes ( \pm S.D.) of Apodemus semotus according to reproductive class in each grid.

\begin{tabular}{|c|c|c|c|c|c|}
\hline & \multicolumn{3}{|c|}{ Male } & \multicolumn{2}{|c|}{ Female } \\
\hline & t.s. & t.d. & t.a. & v.p. and 1 . & v.i \\
\hline \multicolumn{6}{|l|}{ Grid A 1985} \\
\hline Apr. & $29.9 \pm 2.7$ & & - & $26.8 \pm 5.9$ & 17.0 \\
\hline May & $28.9 \pm 3.9$ & & $11.0 \pm 4.2$ & $28.2 \mathrm{t} 5.8$ & $17.0 \pm 3.0$ \\
\hline Jun. & $29.4 \pm 3.9$ & 20.0 & $16.5 \mathrm{f} 0.7$ & $30.7 \mathrm{t} 8.3$ & $19.0 \mathrm{k} 2.7$ \\
\hline Jul. & $28.2 \pm 3.0$ & $22.9 \pm 1.3$ & - & $33.0 \pm 7.9$ & $19.5 \pm 2.1$ \\
\hline Aug. & $27.1 \mathrm{f} 4.7$ & 23.0 & & $30.1 \mathrm{f} 5.3$ & $17.3 \mathrm{f} 1.2$ \\
\hline Sep. & $26.4 \mathrm{f} 2.9$ & & $14.5 \mathrm{k} 2.1$ & $25.4 \mathrm{f} 1.5$ & $14.5 \pm 5.0$ \\
\hline Oct. & $26.8 \mathrm{f} 6.7$ & 22.0 & & - & - \\
\hline Nov. & $26.3 \mathrm{f} 2.1$ & $20.0 \pm 1.41$ & $15.3 \mathrm{k} 5.1$ & $22.5 \mathrm{f} 1.3$ & 10.0 \\
\hline Dec. & $26.7 \pm 2.1$ & 22.0 & $19.7 \pm 1.5$ & $32.5 \pm 5.0$ & $17.0 \pm 2.0$ \\
\hline \multicolumn{6}{|l|}{1986} \\
\hline Jan. & $27.7 \mathrm{f} 2.5$ & $21.8 \mathrm{il} .1$ & $15.7 \pm 3.6$ & $23.0 \mathrm{f} 4.6$ & $16.3 \pm 2.1$ \\
\hline Feb. & $26.4 \mathrm{f} 2.6$ & $21.0 \pm 1.4$ & - & $23.4 \mathrm{f} 2.9$ & - \\
\hline Mar. & $25.8 \pm 2.5$ & & & $28.6 \pm 4.9$ & - \\
\hline Apr. & $27.1 \pm 2.1$ & - & $18.0 \mathrm{k} 4.2$ & $26.3 \mathrm{f} 2.9$ & 16.0 \\
\hline May & $25.8 \mathrm{k} 3.1$ & 20.0 & $18.3 \mathrm{i} 1.5$ & 27.2 f 5.6 & $14.0 \pm 2.8$ \\
\hline Jun. & $25.8 \mathrm{i} 3.4$ & $21.3 \mathrm{f} 1.2$ & 14.0 & $25.8 \mathrm{f} 3.0$ & - \\
\hline Jul. & $28.0 \mathrm{i} 3.6$ & 20.0 & $19.3 \mathrm{t} 4.0$ & $25.7 \mathrm{f} 3.2$ & $18.3 \pm 2.5$ \\
\hline Aug. & $27.31 \mathrm{k} 4.1$ & - & - & $22.2 \pm 3.3$ & - \\
\hline Sep. & $26.7 \mathrm{i} 1.8$ & & $17.7 \mathrm{f} 3.5$ & $28.5 \mathrm{k} 5.2$ & 22.0 \\
\hline Oct. & $25.2 \pm 2.3$ & 25.0 & $16.3 \mathrm{f} 3.9$ & $25.9 \pm 3.1$ & \\
\hline Nov. & $28.0 \mathrm{k} 4.6$ & $23.0 \pm 4.4$ & $19.5 \pm 3.7$ & $26.4 \mathrm{i} 4.3$ & 15.0 \\
\hline Dec. & & $24.5 \mathrm{k} 0.7$ & $17.8 \pm 2.0$ & - & 16.0 \\
\hline \multicolumn{6}{|l|}{1987} \\
\hline Jan. & $23.8 \pm 1.9$ & - & $14.8 \mathrm{k} 4.6$ & $22.3 \mathrm{k} 3.2$ & - \\
\hline Feb. & $24.8 \pm 3.0$ & - & & - & - \\
\hline Mar. & 29.0 & 19.0 & $20.0 \mathrm{k} 5.7$ & $23.5 \pm 0.7$ & - \\
\hline Apr. & $26.2 \mathrm{t} 3.5$ & - & & - & - \\
\hline May & $26.8 \pm 1.1$ & 24.0 & $17.0 \mathrm{t} 2.8$ & 21.0 & 19.0 \\
\hline
\end{tabular}




\begin{tabular}{|c|c|c|c|c|c|}
\hline & & & & & (conti \\
\hline Jun. & 34.0 & & 17.0 & 26.0 & \\
\hline Jul. & $28.0 \pm 2.7$ & 24.0 & - & $23.0 \pm 8.5$ & $13.7 \pm 1.5$ \\
\hline Aug. & $30.3 \pm 3.8$ & - & 15.0 & $26.1 \mathrm{f} 4.8$ & 16.0 \\
\hline Sep. & $24.3 \mathrm{k} 1.5$ & & 18.0 & $24.2 \pm 4.5$ & 19.0 \\
\hline Oct. & $26.5 \mathrm{k} 3.3$ & 20.0 & & & 17.5 \\
\hline Nov. & $26.5 \mathrm{k} 3.5$ & 20.0 & $16.5 \pm 1.7$ & 20.5 & 15.0 \\
\hline Dec. & & $25.5 \mathrm{f} 2.1$ & $15.5 \pm 3.5$ & 24.0 & 20.0 \\
\hline \multicolumn{6}{|l|}{ Grid A'1988 } \\
\hline Aug. & $26.0 \pm 3.1$ & $21.3 \pm 2.5$ & $15.3 \pm 5.5$ & $21.3 \mathrm{k} 3.3$ & $17.8 \pm 2.3$ \\
\hline Sep. & $26.4 \mathrm{f} 2.7$ & $21.3 \pm 1.4$ & $16.8 \mathrm{rfI} 2.6$ & $23.2 \mathrm{t} 3.9$ & 20.0 \\
\hline Oct. & $25.1 \pm 2.4$ & $20.8 \pm 1.0$ & $17.5 \pm 2.1$ & $22.9 \pm 4.0$ & $14.7 \pm 4.5$ \\
\hline Nov. & $23.4 \pm 2.9$ & $20.2 \pm 2.5$ & $14.9 \pm 5.3$ & $24.3 \mathrm{f} 7.8$ & $13.3 \mathrm{k} 3.2$ \\
\hline Dec. & $25.0 \mathrm{f} 5.7$ & $21.0 \pm 2.8$ & $18.1 \mathrm{zk} 2.8$ & $25.0 \mathrm{f} 1.7$ & $13.5 \mathrm{k} 2.6$ \\
\hline 1989 & & & & & \\
\hline Jan. & $24.1 \pm 1.8$ & - & $19.0 \pm 4.1$ & $20.4 \pm 2.9$ & 18.0 \\
\hline Feb. & $26.2 \mathrm{f} 2.2$ & $21.3 \mathrm{f} 0.6$ & - & $20.4 \pm 2.7$ & - \\
\hline Mar. & $27.3 \pm 1.8$ & $22.0 \mathrm{f} 1.4$ & 19.0 & $25.8 \mathrm{k} 6.8$ & - \\
\hline Apr. & $24.9 \pm 2.2$ & - & 12.0 & $25.0 \pm 2.7$ & 10.0 \\
\hline May & $24.7 \pm 4.0$ & $23.6 \pm 2.6$ & $13.0 \mathrm{zk} 4.6$ & $21.3 \pm 2.9$ & $11.0 \pm 4.8$ \\
\hline Jun. & $30.1 \mathrm{f} 1.9$ & 19.0 & $14.5 \mathrm{i} 1.7$ & $26.6 \mathrm{k} 4.9$ & $15.0 \pm 1.0$ \\
\hline Jul. & $29.2 \pm 4.1$ & $22.3 \pm 2.1$ & $11.8 \pm 2.4$ & $26.6 \mathrm{f} 5.7$ & $15.0 \pm 1.6$ \\
\hline \multicolumn{6}{|l|}{ Grid B 1985} \\
\hline Apr. & $25.4 \mathrm{t} 2.3$ & 22.0 & 9.0 & $25.2 \mathrm{f} 2.8$ & $17.3 \pm 6.0$ \\
\hline May & $24.0 \mathrm{f} 3.5$ & & 15.311 .2 & $23.7 \mathrm{f} 5.7$ & $15.5 \pm 2.7$ \\
\hline Jun. & 21.5 & $18.8 \pm 2.0$ & $15.4 \pm 3.2$ & $20.9 \mathrm{f} 1.7$ & $17.9 \mathrm{i} 2.7$ \\
\hline Jul. & 25.0 & $21.7 \pm 1.3$ & 10.0 & $21.71 \mathrm{k} 3.9$ & $18.1 \pm 1.1$ \\
\hline Aug. & $26.3 \pm 3.7$ & & - & $20.2 \pm 2.8$ & \\
\hline Sep. & $21.1 \mathrm{t} 2.4$ & & & $19.0 \pm 2.8$ & \\
\hline Oct. & 25.0 & & - & 21.0 & \\
\hline Nov. & $27.0 \mathrm{f} 3.6$ & $20.8 \pm 1.8$ & & $23.3 \pm 3.2$ & \\
\hline Dec. & & $19.8 \pm 0.8$ & $15.8 \pm 1.8$ & 22.5 & $15.1 \pm 0.9$ \\
\hline 1986 & & & & & \\
\hline Jan. & $23.6 \pm 3.2$ & $21.0 \mathrm{k} 1.4$ & $13.3 \mathrm{f} 1.8$ & $22.3 \pm 3.2$ & $15.4 \pm 3.9$ \\
\hline Feb. & $24.4 \mathrm{i} 4.3$ & $20.8 \pm 3.1$ & 17.0 & 21.0 & $14.3 \mathrm{f} 0.6$ \\
\hline Mar. & $25.8 \pm 2.8$ & - & & $20.9 \pm 3.3$ & $14.3 \mathrm{zk} 1.3$ \\
\hline Apr. & $25.9 \pm 3.0$ & & & $23.6 \mathrm{f} 4.1$ & \\
\hline May & $24.9 \pm 1.6$ & 22.0 & $13.5 \pm 0.7$ & $21.8 \pm 3.3$ & 11.0 \\
\hline Jun. & $24.1 \pm 0.6$ & 21.0 & $18.3 \mathrm{k} 1.4$ & $23.9 \mathrm{f} 3.8$ & $15.6 \mathrm{i} 1.7$ \\
\hline Jul. & $28.7 \pm 2.5$ & $22.7 \pm 1.5$ & 17.0 & $23.0 \mathrm{f} 2.4$ & $17.5 \mathrm{t} 2.1$ \\
\hline Aug. & $26.0 \pm 3.4$ & - & $14.0 \mathrm{k} 4.2$ & $20.6 \pm 0.8$ & $12.5 \pm 4.9$ \\
\hline Sep. & $22.5 \mathrm{f} 1.3$ & & - & 24.0 & 16.0 \\
\hline Oct. & $25.7 \pm 2.3$ & & $18.0 \pm 3.6$ & - & $17.5 \mathrm{k} 2.1$ \\
\hline
\end{tabular}

Abbreviations as in Table 8.

shown in Table 9 . The body weight (mean \pm S.D.) of adult males with fully descended testes was heavy $(26.9 \pm 2.0 \mathrm{~g})$ in Grids A and A' (Cryptomeria plantatidn habitat), compared with that in Grid B (Chamaecyparis habitat) $(24.7 \pm 1.9 \mathrm{~g}$ ), the former being significantly greater than the latter $(t=2.61, P<0.05)$. Likewise, females with perforated vaginal orifice and lactating females had heavier body weights in Cryptomeria plantation habitat $\left(\begin{array}{lll}25.1 & 43.2 \mathrm{~g}\end{array}\right)$ than in Chamaecyparis habitat $(22.1 \pm 1.6$ g) $(t=3.25, P<0.05)$. Males with fully descended testes had heavier body weights at 
the onset of breeding season, i.e. in spring and late summer in all grids, except for late summer in 1985 in Grid A, when their body weights decreased; however, female body weights showed no clear pattern of seasonal fluctuation (cf. Table 9).

\section{Food habits}

The dietary analysis of stomach contents was made only in February (the dry season) and August (the wet season) by volume. In February, green components of plants occupied the greater part of the diet. In August, greencomponents of plants and fungi constituted the main part of the diet (Table 10). Most of the green plant material consisted of green leaves and fruit flesh. Green leaves with trichomes were present in most samples, but could not be identified to species. In both months, there was no evidence that the three dominant plant species (Polygonumchinense, Polygonum thunbergii and Hydrocotyle nepalensis) were used for food.

Mice ate more animal matter in February than in August; considering the small sample sizes, however, the difference in the amount was not very great. It is worty of note that large quantities of fungi were eaten by mice in August (41.6\%); on the contrary, no fungi were eaten in February.

Table 10. The diet of Apodemus semotus, given by volume of stomach contents (mean percentage).

\begin{tabular}{lcccccc}
\hline $\begin{array}{l}\text { Month } \\
\text { (Season) }\end{array}$ & $\begin{array}{c}\text { Sample } \\
\text { size }\end{array}$ & $\begin{array}{c}\text { Green } \\
\text { plant }\end{array}$ & Fungi & Seed Animal Other \\
\hline February (dry) & 8 & 86.6 & 0 & 6.4 & 3.2 & 3.8 \\
August (wet) & 8 & 47.5 & 41.6 & 5.1 & 0.4 & 5.4 \\
\hline
\end{tabular}

\section{DISCUSSION}

\section{Comparison of population densities in the genus A podemus}

Comparison with other works on densities of A podemus species is difficult because methodology differs markedly from one another. In general, the population of $\mathbf{A}$. semotus in the Alisan, Taiwan was dense with the highest density $(66.7 /$ ha) in August 1986 in Grid A, in comparison with populations of other Apodemus species. In Europe, the densities of A. sylvaticus populations in woodlands are generally lower than those of A. semotus, with minimal spring densities of only 5 and less/ha and maximal autumn densities of about 30/ha (Watts, 1969; Crawley, 1970; Treussier, 1977; Gibson and Delany, 1984); however, a higher density $(90.9 /$ ha) than in A. semotus is obtained from habitats having monospecific occupacy(Jamon, 1986).

In Japan, the population densities of $\mathbf{A}$. argenteus, a species closely related to $\mathbf{A}$. semotus, are calculated with 23.0 / ha at maximum and 5.6 / ha at minimum by the livetrapping method through four years (Nishikata, 1979). On the other hand, A. speciosus has a maximal density of $90 /$ ha in a small stand (Kondo, 1980).

Mice having high population densities are regarded as being habitat generalists (Gurnell, 1985 for A. sylvaticus; Adler et al., 1987 for Peromyscus leucopus). Thus, A . 
semotus is a species with wide habitat tolerance in the Alisan Alpine Forest Park. The other small mammals collected in this study consisted of one rat species (Niviventer culturatus), two vole species (Microtus kikuchii and Eothenomys melanogaster) and three shrew species (Anourosorex squamipes, Soriculus fumidus and Crocidura sp.), but their numbers were relatively small (Table 1). Therefore, they seemed not to compete strongly with A. semotus. Competition between rodent species is said to be most commonly based on food and space. If the resources are very limited in a given space (e.g. a monoculture plantation forest), one species will be dominant over the other.

On the other hand, Apodemus species are generally sympatric in Europe ( $A$. sylvaticus and $A$. flavicollis) (Montgomery, 1980) and Japan (A. argenteus and $A$. speciosus)(Doi and Iwamoto, 1973; Shioya et al., 1990). According to the population study of Microtus townsendii, one area contains M.oregoni and Peromyscus maniculatus when $M$. townsendii is at low densities, but the two potential competitors disappear when $M$. townsendii increases above 100/ha (Taitt and Krebs, 1985). However, there is one other concept that competition between these sympatric species may exist without any effects on the population dynamics or densities (Montgomery, 1981; Wolff, 1985). In Taiwan, A. semotus occurs only in mountainous regions and another species of Apodemus (A. agrarius) is distributed only in the lowland (Aoki and Tanaka, 1941). The distribution of the two Apodemus species was apparently allopatric. Consequently, $A$. semotus never competes with $A$. agrarius. It was revealed that the high densities of $A$. semotus probably resulted from habitats having monospecific occupancy.

\section{Mecahnisms of annual fluctuations in the genus Apodemus}

In the Chamaecyparis habitat (Grid B), the population of A. semotus showed the demographic pattern having the low density, short residence and high recruitment rate compared with that in the Cryptomeria plantation habitat, suggesting that the former habitat was less suitable for the wood mouse than the latter habitat (Grids A and A'). In particular, the mice were lighter in body weight and had more trap-death in the Chamaecyparis habitat than in the Cryptomeria habitat. The relationship between the mice inhabiting the Chamaecyparis habitat and Cryptomeria plantation habitat corresponded to the relationship between dispersing and resident animals in terms of numbers and body weights, i.e. young mice with lighter body weight were common in the Chamaecyparis habitat, which may have been dispersing. In this connection, dispersing mice were usually subordinate (Adler et al., 1984 for Peromyscus Zeucopus). Probably Grid B, like a patchy habitat (Gottfried, 1982 for Peromyscus Zeucopus), or a disturbed habitat (Linzey, 1989 for Peromyscus Zeucopus), seemed to have functioned as a dispersal sink in the small mammal ecosystem, as pointed out by Lidicker (1975).

Although fluctuations in the number of A. sylvaticus in West Germany show a three-year cycle (Wendland, 1981), there is little direct evidence for three-to four-year cyclic fluctuations of the same species in British woodland (Flowerdew, 1985). In this respect, A. semotus had the lowest densities in 1987 (out of four years of the survey period from 1985 to 1989) in the Cryptomeria plantation (Grids A and A'), but this phenomenon seemed not to support a regular multi-annual cycle. Thus, it might be said that the change in density of $A$. semotus throughout the year (Fig. 2a) reflected generally the typical annual cycle of A. sylvaticus in Europe (Flowerdew, 1978) and 
Peromyscus spp. in North America (Terman, 1968). The annual fluctuation of A. sylvaticus in Britain consists of high numbers in late autumn of winter followed by a spring decline and often stationary numbers in summer (Flowerdew, 1985).

By comparison with the characteristics of A. sylvaticus fluctuations, it was revealed that A. semotus had the following most striking features: the population usually had a highest peak of density in August, a slight peak in winter and declines in not only autumn but also spring. In this connection, two essential differences between A. semotus and A. sylvaticus need to be explained, i.e. (1) Why did A. semotus populations have the highest peak of density in August about five months earlier than A. sylvaticus? (2) Why did the density decline sharply in autumn? Our discussion takes the focus on the above questions, together with the slight winter peak and the spring decline of the density in $A$. semotus, respectively.

1) Why did the peaks of density occur in August and winter?

The highest density in August:

The answer to this question lies mainly in food supplies. The peak in population density of $A$. sylvaticus in winter results from good survival rates in autumn, and the supply of seed food often improves at this time (Watts, 1968). On the other hand, good survival rate appeared in summer (Fig. 3), when large quantities of fungi were taken by $A$. semotus in monoculture habitats of Crypromeria japonica. A. semotus seemed not to be fond of Cryptomeria seeds as food, as pointed out by Tatsukawa and Murakami (1976) for A. speciosus. During the growing period of fungi in the wet season, fungi might provide the wood mouse with an important source in the environment with shortage of food supply owing to the low diversity of plant communities as in Cryptomeria monoculture, being considered as the reason for the good survival rate in summer. In this connection, also in the Australian smoky mouse (Pseudomys fumeus), it is worthy of note that there is a strongly positive relationship between the population number and the percentage of fungi in the food items (Cockburn, 1981). So far, A. sylvaticus has been regarded as a mainly seed-eating animal, but when seeds are scarce it becomes an opportunistic eater on other sources of concentrate food (Watts, 1968; Obrtel and Holisova, 1979). Diets of A. semotus inhabiting the monocultural plantations also might reflect opportunism responding to the seasonal cahnge of foods.

Next, the pattern of breeding activity also seems to exert a strong influence on annual changes of density in rodents (Krohne et al., 1988 for Peromyscus spp.; Keller, 1985 for Microtus spp.). In A. semotus the breeding season lasted for a long period from late February or March to late October or early November with bimodal peaks in March-May and August-October, respectively, whereas in A. sylvaticus the breeding season extends only for six months from April to September with a single peak (Clarke, 1985). The causation for the highest peak of the A. semotus density in August was involved with the disappearance of overwintered mice (the autumn-born individuals in the previous year) by June and a consequent influx of immature spring-born individuals added into the population in summer. In this connection, the percentage of newly marked individuals including many male transients was high at the onset of breeding in August, because adult mice (the above spring-born individuals) maturing in the year of their birth were more tolerant of other individuals than overwintered mice, as pointed in A. sylvaticus by Flowerdew (1974). Although transients in grid-trapping 
studies are not always regarded as dispersers (Wolton and Flowerdew, 1985), the dispersal movements of males from adjacent areas at the beginnig of the breeding season appear to be responsible for increase in density of A. semotus population.

The slight peak in winter:

Both adult males and adult females are aggressive to juveniles and prevent their recruitment, as pointed out by Flowerdew (1985) for Apodemus spp. The fact that the loss of $A$. semotus adults in autumn (Fig. 3) occurred in the end of the second peak of breeding and the consequent recruitment of many juveniles commenced with their appearance in winter (Fig. 5) becomes enough explanation for the slight winter peak.

\section{2) Why did the declines of density occur in autumn and spring?}

The autumn decline:

This question is more difficult to answer. In A. semotus, the most severe decline of density between September and November in all years, except for the decline in 1986, involved low survival rates (Fig. 3). The possible reason for the autumn decline is suggested by natural death of the wood mouse. However, the cues to prompting mortality in adults are still unknown.

The spring decline:

The decline appeared from February to April as in many species of small rodents, e.g. the abrupt disappearance of a large proportion of mice occurs just as the population is about to breed in spring (Montgomery, 1989b). Recently, one hypothesis proposes that the spring decline is a result of socially-induced mortality or dispersal caused by spacing behaviour among animals coming into breeding condition (Krebs and Boonstra, 1978 for Microtus townsendii; Adler et al., 1987 for Peromyscus leucopus).

With respect to this hypothesis, studies that concentrate on behavioural regulation have demonstrated that adult males of $A$. sylvaticus are aggressive and territorial during the breeding season and appear to reduce recruitment of young or socially subordinate individuals (Flowerdew, 1974, 1978; Gurnell, 1978). However, the effect of breeding females on population regulation has not been documented for the genus Apodemus (Montgomery, 198913). In A. speciosus of Japan, only the females have exclusive home ranges, and resident females prevent the settling of immigrant females (Kondo, 1977, 1982). The demography of A. semotus females appeared to be coincide with the above results. At low densities in Grid A' in spring, although overt aggression of females was not studied, the lowest recruitment rate (Fig. 5), together with their exclusive home range (unpublished data), was apparently maintained.

The conclusion can be expressed as follows: The high densities of A. semotus probably resulted largely from habitats having monospecific occupancy. The annual fluctuation in density was characterized by a highest peak in August, a slight peak in winter and declines in both autumn and spring. The highest peak at the onset of breeding in August was caused by the high percentage of new individuals including many male transients entering into the population. The spring decline in A. semotus was qualitatively similar to that in $A$. sylvaticus, and spacing behaviour of adults might accout for the modification in demographic parameters associated with the beginning of two peaks in the annual breeding cycle. 


\section{ACKNOWLEDGEMENTS}

We thank Emeritus Professor Teru Aki Uchida of Kyushu University for criticisms during this study and for constructive advice on the earlier draft; Professor E. W. Jameson, Jr., Department of Zoology, University of California for comments on the manuscript. Special thanks are extended to Professor Paul S. Alexander of Tunghai University, Taiwan for his help and encouragement throughout this study. We are also indebted to graduate students of Biology Department, Tunghai University for their kind assistance in the field work. This study was supported in part by the National Science Council of Republic of China, Taiwan.

\section{REFERENCES}

Adler, G. H., L. M. Reich and R. H. Tamarin 1984 Characteristics of white-footed mice in woodland and grassland in eastern Massachusetts. Acta Theriol.,29: 57-62

Adler, G. H., M. L. Wilson and M. J. Derosa 1987 Effects of adults on survival and recruitment of Peromyscus leucopus. Can. J.Zool., 65: 2519-2523

Aoki, B. and R. Tanaka 1941 The rats and mice of Formosa illustrated. Mem.Fac. Sci. Taihoku Imp. Univ., 22: 121-191

Chitty, D. and E. Phipps 1966 Seasonal changes in survival in mixed population of two species of vole. J. Anim. Ecol., 35: 313-331

Clarke, J. R. 1985 The reproductive biology of the bank vole (Clethrionomys glareolus) and the wood mouse (Apodemus sylvaticus). Symp.zool. Soc. Lond., 55: 33-59

Cockburn, A. 1981 Population regulation and dispersion of the smoky mouse, Pseudomys fumeus. II. Spring declines, breeding success and habitat heterogeneity. Aust. J. Ecol., 6: 255-266

Crawley, M. C. 1970 Some population dynamics of the bank vole, Clethrionomys glareolus and the wood mouse, Apodemus sylvaticus in mixed woodland. J. Zool., Lond., 160: 71-89

Doi, T. and T. Iwamoto 1973 A preliminary study on the seasonal fluctuation of the population density of the Japanese forest mice, Genus Apodemus in natural forest in Kyushu. Reports from the Ebino Bio. Lab., Kyushu Univ., 1: 64-72

Flowerdew, J. R. 1974 Field and laboratory experiments on the social behaviour and population dynamics of the wood mouse (Apodemus sylvaticus). J. Anim. Ecol., 43: 499-511

Flowerdew, J. R. 1978 Residents and transients in wood mouse populations. In "Population Control by Social Behaviour", ed. by E. J. Ebling and D. M. Stoddart, Inst. of Biology, London, pp. 49-66

Flowerdew, J. R. 1985 The population dynamics of wood mice and yellow-necked mice. Symp.zool. Soc. Lond., 55: 315-338

Gibson, D. St. C. and M. J. Delany 1984 The population ecology of small rodents in Pennine woodland. J. Zool., Lond., 203: 63-85

Gottfried, B. M. 1982 A seasonal analysis of small mammal populations on woodlot islands. Can. J. Zool., 60: $1660-1664$

Gurnell, J. 1978 Seasonal changes in numbers and male behavioural interaction in a population of wood mice, Apodemus sylvaticus. J. Anim. Ecol., 47: 741-755

Gurnell, J. 1985 Woodland rodent communities. Symp.zool.Soc. Lond., 55: 377-411

Hilborn, R., J. A. Redfield and C. J. Krebs 1976 On the reliability of enumeration for mark and recapture census of voles. Can. J.Zool., 54: 1019-1024

Jamon, M. 1986 The dynamics of wood mice (Apodemus sylvaticus) populations in the Camargue. J. Zool., Lond., 208: 569-582

Keller, B. L. 1985 Reproductive patterns. In "Biology of New World Microtus", ed. by R. H. Tamarin, 
Amer. Soc. Mamm., Spec. Publ., pp. 725-778

Kondo, N. 1980 Seasonal fluctuation of population size, activity and activity area of Apodemus speciosus ainu (Thomas) in small stand. J.Mamm.Soc. Japan, 8: 129-138 (in Japanese with English abstract)

Kondo, T. 1977 Social behavior of the Japanese wood mouse, Apodemus specious (Temminck) in the field. Jap. J. Ecol., 27: 301-310

Kondo, T. 1982 A population study of the Japanese wood mouse, Apodemus speciosus (Mammalia: Muridae) with reference to its social behavior. Res. Popul.Ecol., 24: 85-96

Krebs, C. J. 1966 Demographic changes in fluctuating populations of Microtus californicus. Ecol. Monogr, 36: 239-273

Krebs, C. J. and R. Boonstra 1978 Demography of the spring decline in populations of the vole, Microtus townsendii. J. Anim. Ecol., 47: 1007-1015

Krohne, D. T., J. F. Merritt, S. H. Vessey and J. 0. Wolff 1988 Comparative demography of forest Peromyscus. Can, J. Zool., 66: 2170-2176

Lidicker, W. Z., Jr. 1975 The role of dispersal in the demography of small animals. In "Small Mammals: Their Productivity and Population Dynamics", ed. by F. B. Golley, R. Petrusewicz and L. Ryskowski, Cambridge Univ. Press, pp. 103-128

Lin, L.-K. and I. J. Lin. 1988 The relative efficiency of two size of Sherman live-traps. Yushania, 5: 21-23 (in Chinese with English abstract)

Linzey, A. V. 1989 Response of the white-footed mouse (Peromyscus leucopus) to the transition between disturbed and undisturbed habitats. Can. J. Zool., 67: 505-512

Montgomery, W. I. 1980 Spatial organization in sympatric populations of Apodemus sylvaticus and A. flavicollis (Rodentia: Muridae). J.Zool., Lond., 192: 379-401

Montgomery, W. I. 1981 A removal experiment with sympatric populations of Apodemus sylvaticus (L.) and A. flavicollis (Melchior) (Rodentia: Muridae). Oecologia (Berl.), 51: 123-132

Montgomery, W. I. 1989a Population regulation in the wood mouse, Apodemus sylvaticus.I. Density dependence in the annual cycle of abundance. J. Anim.Ecol., 58: 465-476

Montgomery, W. I. 1989b Population regulation in the wood mouse, Apodemus sylvaticus. II. Density dependence in spatial distribution and reproduction. J. Anim. Ecol., 58: 477-494

Nishikata, S. 1979 Ecological studies on the population of Apodemus argenteus argenteus in Mt. Kiyosumi, Chiba Pref. I. A life cycle and fluctuations of population size. J. Mamm. Soc. Japan, '7: 240-253 (in Japanese with English abstract)

Obrtel, R. and V. Holisova 1979 The food eaten by Apodemus sylvaticus in a spruce monoculture. Folia Zool., 29: 299-310

Shioya, K., S. Shiraishi and T. A. Uchida 1990 Microhabitat segregation between Apodemus argenteus and A. speciosus in northern Kyushu. J. Mamm. Soc. Japan, 14: 105-118

Taitt, M. J. and C. J. Krebs 1985 Population dynamics and cycles. In "Biology of New World Microtus", ed. by R. H. Tamarin, Amer. Soc. Mamm., Spec. Publ., pp. 567-620

Tatsukawa, K. I. and 0. Murakami 1976 On the food utilization of the Japanese wood mouse Apodemus speciosus (Mammalia: Muridae). Physiol.Ecot. Japan, 17: 133-144 (in Japanese with English summary)

Terman, C. R. 1968 Population dynamics. In "Biology of Peromyscus", ed. by J. A. King, Amer. Soc. Mamm., Spec. Publ., pp. 412-455

Treussier, M. 1977 Dynamics of a population of field mouse. Acta Theriol., 22: 207-214

Watts, C. H. S. 1968 The food eaten by wood mice (Apodemus sylvaticus) and bank voles (Clethn'onomys glareolus) in Wytham Woods, Berkshire. J. Anim. Ecol., 37: 25-42

Watts, C. H. S. 1969 The regulation of wood mouse (Apodemus sylvaticus) numbers in Wytham Woods, Berkshire. J. Anim. Ecol., 38: 285-304

Wendland, V. 1981 Cyclic population changes in three mouse species in the same woodland. Oecologia (Berl.), 48: 7-12 
Wolff, J. 0. 1985 Comparative population ecology of Peromyscusleucopus and Peromyscus maniculatus. Can. J. Zool., 63: 1548-1555

Wolton, R. J. and J. R. Flowerdew 1985 Spatial distribution and movements of wood mice, yellow ${ }^{-}$ necked mice and bank voles. Symp.zool.Soc. Lond., 55: 249-275

Zhang, J. 1989 On the population age and reproduction of Apodemus agrarius in Beijing area. Acta Theriol. Sinica, 9: 41-48 (in Chinese with English abstract) 